\title{
Options for empagliflozin in combination therapy in type 2 diabetes mellitus
}

This article was published in the following Dove Press journal:

International Journal of General Medicine

25 May 2016

Number of times this article has been viewed

\author{
Kenneth S Hershon ${ }^{1,2}$ \\ 'North Shore Diabetes and Endocrine \\ Associates, New Hyde Park, \\ ${ }^{2}$ Department of Medicine, Hofstra \\ Northwell School of Medicine, \\ Hempstead, NY, USA
}

Objective: To update clinicians with an overview of empagliflozin for the treatment of type 2 diabetes mellitus (T2DM), with focus on use in combination regimens.

Methods: Keyword searches were conducted in the Medline database to identify literature reporting clinical trials of at least 12 weeks' duration using empagliflozin treatment in patients with T2DM. Results: When given as monotherapy or in combination therapy (as add-on or single-pill therapy) with metformin, pioglitazone, sulfonylurea, linagliptin, and insulin, empagliflozin produced clinically meaningful reductions in glycated hemoglobin levels, plasma glucose concentrations, bodyweight, and blood pressure. These changes were sustained during long-term treatment. In a dedicated cardiovascular event trial, empagliflozin on top of standard of care demonstrated a significant reduction in the risk of cardiovascular mortality and all-cause mortality. Across the clinical trials, empagliflozin combination therapies were well tolerated, and empagliflozin used alone was not associated with increased risk of hypoglycemia versus placebo. Indeed, the combination of empagliflozin and metformin had a significantly reduced rate of hypoglycemia compared with the combination of metformin and a sulfonylurea. On the other hand, empagliflozin treatment did have increased risk of genital infections compared with placebo. In clinical trials to date, diabetic ketoacidosis was not seen more frequently with empagliflozin than with placebo, but physicians should be alert to the possibility of this rare event.

Conclusion: Empagliflozin has the potential to make an important contribution to the treatment of patients with T2DM. In some patients, empagliflozin may be used as monotherapy, but it is most likely to be used in combination with other therapies. Given the reduced risk of mortality seen when empagliflozin was added to standard care in patients at high cardiovascular risk, as well as the lack of alternative options for patients at lower cardiovascular risk, empagliflozin may be added to ongoing regimens for a significant proportion of patients.

Keywords: combination therapy, DPP-4 inhibitors, empagliflozin, metformin, SGLT2 inhibitors, type 2 diabetes

\section{Introduction}

Selective sodium glucose co-transporter-2 (SGLT2) inhibitors target the kidney to reduce glucose reabsorption and promote urinary glucose excretion (ie, glucosuria), thereby lowering hyperglycemia in patients with type 2 diabetes mellitus (T2DM). ${ }^{1,2}$ In fact, patients starting SGLT2 inhibitor therapy may need to be advised that they will test positive for urinary glucose, since many still perceive this as a sign of poor control. Urinary glucose excretion caused by SGLT2 inhibitor therapy also promotes modest reductions in blood pressure (BP) and bodyweight, ${ }^{3}$ potential additional advantages for many patients with T2DM who are frequently overweight and hypertensive.
Correspondence: Kenneth S Hershon Associates, 3003 New Hyde Park Road, Suite 20I, New Hyde Park, NY I I042, USA

Tel +I 5163270850

$\mathrm{Fax}+\mathrm{I} 5163270920$

Email khershon@nsdea.com
International Journal of General Medicine 2016:9 I55-172

(cc) (1) (2) ๑ 2016 Hershon. This work is published and licensed by Dove Medical Press Limited. The full terms of this license are available at https:/www.dovepress.con/terms.php cc. hereby accept the Terms. Non-commercial uses of the work are permitted without any further permission from Dove Medical Press Limited, provided the work is properly attributed. For permision for commercial use of this work, please see paragraphs 4.2 and 5 of our Terms (htpps://www.dovepress. com/terms.php).
Dovepress

http://dx.doi.org/10.2147/IIGM.SI 00288

5


A number of SGLT2 inhibitors are in clinical development, and three are currently approved in the United States (US): canagliflozin, ${ }^{4}$ dapagliflozin, ${ }^{5}$ and empagliflozin. ${ }^{6}$ All three are administered as oral, once-daily regimens. Empagliflozin is the most recently available, but has subsequently become the first drug in the class to demonstrate cardiovascular safety. ${ }^{7}$ Even more excitingly, it was the first antihyperglycemic drug ever to show cardiovascular risk reduction in a dedicated cardiovascular outcome study although metformin and pioglitazone have previously been associated with reductions in cardiovascular risk as secondary end points - no drug has previously demonstrated reduced risk of clinical cardiovascular events in a prospective outcomes trial. ${ }^{8,9}$

The empagliflozin cardiovascular outcome study, known as EMPA-REG OUTCOME, was conducted in more than 7,000 T2DM patients at high cardiovascular risk. ${ }^{7}$ Patients were already receiving the standard of care for lipids and $\mathrm{BP}$ as well as for blood glucose, with approximately $74 \%$ on metformin, and more than $50 \%$ on insulin. Since empagliflozin is available in two doses, patients were randomized to either of the empagliflozin doses (10 or $25 \mathrm{mg}$ ) or placebo, and the results with both empagliflozin doses were pooled. During the study, all cardiovascular outcome events and all deaths were prospectively adjudicated and the primary outcome was time to occurrence of major adverse cardiovascular events (MACE: death from cardiovascular causes, nonfatal myocardial infarction, or nonfatal stroke). The study was stopped after a median observation period of 3.1 years, when 772 primary events were recorded. Patients assigned empagliflozin had a $14 \%$ reduction in risk of a primary outcome event versus patients assigned placebo (hazard ratio, 0.86; 95\% confidence interval [CI], 0.74-0.99; $P<0.001$ for noninferiority and $P=0.04$ for superiority). This was mainly driven by a $38 \%$ reduction in the risk of death from cardiovascular causes, while risks for nonfatal myocardial infarction or nonfatal stroke were not significantly different between the empagliflozin and placebo groups. The study investigators also noted that the reduction in risk of death occurred early in the trial and was continued throughout follow-up. There was no significant difference between the groups in the risk of hospitalization for angina, but the empagliflozin group had significantly lower risks of death from any cause and hospitalization for heart failure versus the placebo group.

While these results are exciting for empagliflozin and the landscape of T2DM treatment in general, it is worth remembering that the patients in this study are not representative of all T2DM patients. Notably, they were specifically recruited due to their high cardiovascular risk, and most had been diagnosed with T2DM for at least 5 years, probably reflecting the relatively high proportion on insulin. However, the addition of empagliflozin to ongoing stable regimens does reflect widespread use of empagliflozin in clinical practice.

As with all new drugs for T2DM, a number of Phase II and III clinical trials have been conducted for empagliflozin to test the drug in different groups of patients with T2DM, as well as in combination regimens with the other most common drug classes. A meta-analysis of empagliflozin studies was published in $2014,{ }^{10}$ but since then a number of studies have been reported in the literature, and a further meta-analysis is reportedly planned. ${ }^{11}$ This narrative review provides a broad overview of empagliflozin, with an updated review of clinical trial data. The focus of the review is on empagliflozin in combination regimens, because empagliflozin - like dapagliflozin and canagliflozin - is expected to be most commonly used in combination with other glucose-lowering drugs. When discussing combination regimens for T2DM, single-pill and fixed-dose options inevitably come to mind, and single-pill tablets combining empagliflozin with other glucose-lowering agents have been developed. ${ }^{12-14}$ However, in this review, studies reporting separate drugs used in combination as well as single-pill combinations are considered to allow physicians to first select an appropriate regimen, and then determine whether a single-pill combination is suitable (if one is available). After reviewing the empagliflozin studies, the key differentiators to consider when choosing an SGLT2 inhibitor are considered.

\section{Review methods}

For this narrative review, a Medline search was conducted in June 2015 for the keyword "empagliflozin" in any field. No restrictions were placed on language or on the start date for record entries. Abstracts were reviewed, and records reporting randomized, double-blind clinical trials of empagliflozin lasting 12 weeks or longer and conducted in patients with T2DM were selected. Of the 105 results retrieved that contained the key word "empagliflozin", 16 publications fulfilled the stated review criteria: ${ }^{15-30}$ empagliflozin monotherapy studies $(n=3)$; studies of empagliflozin as add-on therapy to stable regimens of other antidiabetes drugs ( $\mathrm{n}=9$ ); single-pill combination studies $(\mathrm{n}=2)$; and various regimens that included a mixture of monotherapy and combination therapy $(n=2)$.

\section{Empagliflozin monotherapy}

Key efficacy and safety data from studies of empagliflozin monotherapy are presented in Tables 1 and $2 .{ }^{15-17}$ In summary, 
Table I Empagliflozin monotherapy studies: key efficacy data

\begin{tabular}{|c|c|c|c|c|c|c|c|c|c|}
\hline \multirow[t]{2}{*}{ Study } & \multirow[t]{2}{*}{ Study details } & \multirow{2}{*}{$\begin{array}{l}\text { Regimen } \\
\text { details }\end{array}$} & \multirow[t]{2}{*}{$\mathbf{N}$} & \multirow{2}{*}{$\begin{array}{l}\text { Treatment } \\
\text { and dose } \\
(\mathrm{mg} / \mathrm{d})\end{array}$} & \multicolumn{5}{|c|}{ Efficacy parameters (change from baseline) ${ }^{a}$} \\
\hline & & & & & $\begin{array}{l}\mathrm{HbA}_{\mathrm{Ic}} \\
\text { (\%) }\end{array}$ & $\begin{array}{l}\text { FPG } \\
(\mathrm{mg} / \mathrm{dL})\end{array}$ & $\begin{array}{l}\text { FPG } \\
(\mathrm{mmol} / \mathrm{L})\end{array}$ & $\begin{array}{l}\text { Body weight } \\
\text { (kg) }\end{array}$ & $\begin{array}{l}\text { SBP } \\
(\mathrm{mmHg})\end{array}$ \\
\hline \multirow{5}{*}{$\begin{array}{l}\text { Roden } \\
\text { et al }{ }^{15}\end{array}$} & \multirow[t]{5}{*}{ Phase III, 24 wk } & \multirow[t]{5}{*}{ Monotherapy } & 228 & Pbo & 0.08 & 11.7 & 0.65 & -0.33 & -0.3 \\
\hline & & & 224 & EMPA 10 & -0.66 & -19.5 & -1.08 & -2.26 & -2.9 \\
\hline & & & 224 & EMPA 25 & -0.78 & -24.5 & -1.36 & -2.48 & -3.7 \\
\hline & & & 223 & SITA I00 & -0.66 & -6.8 & -0.38 & 0.18 & 0.5 \\
\hline & & & 87 & $\begin{array}{l}\text { EMPA } 25 \\
\left(\mathrm{HbA}_{\mathrm{Ic}}>10.0 \%\right)\end{array}$ & -3.70 & -87.6 & -4.86 & -2.43 & -4.0 \\
\hline \multirow{5}{*}{$\begin{array}{l}\text { Ferrannini } \\
\text { et al }{ }^{16}\end{array}$} & \multirow[t]{5}{*}{ Phase II, 12 wk } & \multirow[t]{5}{*}{ Monotherapy } & 82 & Pbo & 0.1 & 0.72 & 0.04 & -0.75 & Not reported \\
\hline & & & 81 & EMPA 5 & -0.4 & -23.24 & -1.29 & -1.81 & Not reported \\
\hline & & & 81 & EMPA 10 & -0.5 & -29.00 & -1.61 & -2.33 & Not reported \\
\hline & & & 82 & EMPA 25 & -0.6 & -30.99 & -1.72 & -2.03 & Not reported \\
\hline & & & 80 & MET (O/L) & -0.7 & -29.91 & -1.66 & -1.32 & Not reported \\
\hline \multirow{5}{*}{$\begin{array}{l}\text { Kadowaki } \\
\text { et al }{ }^{17}\end{array}$} & \multirow[t]{5}{*}{ Phase II, 12 wk } & \multirow[t]{5}{*}{ Monotherapy } & 109 & Pbo & 0.30 & 4.06 & 0.23 & -0.9 & -1.38 \\
\hline & & & 110 & EMPA 5 & -0.42 & -22.65 & -1.26 & -2.5 & -2.85 \\
\hline & & & 109 & EMPA 10 & -0.40 & -25.28 & -1.40 & -2.6 & -5.57 \\
\hline & & & 109 & EMPA 25 & -0.65 & -33.70 & -1.87 & -2.9 & -4.60 \\
\hline & & & 110 & EMPA 50 & -0.61 & -32.54 & $-1.8 \mid$ & -3.1 & -5.21 \\
\hline
\end{tabular}

Notes: aWhere publications reported FPG in $\mathrm{mg} / \mathrm{dL}$, these were converted to $\mathrm{mmol} / \mathrm{L}$ using a factor of 0.0555 , and vice versa. To convert $\mathrm{HbA}$ from $\%$ to $\mathrm{mmol} / \mathrm{mol}$, use the calculator from the NGSP (National Glycohemoglobin Standardization Program) available from http://www.ngsp.org/convertl.asp. MET dosing: I000 mg/d for 4 weeks, thereafter increased to $1000 \mathrm{mg}$ twice daily, or up to maximum tolerated dose, if needed.

Abbreviations: EMPA, empagliflozin; FPG, fasting plasma glucose; HbA , glycated hemoglobin; MET, metformin; O/L, open label; Pbo, placebo; SBP, systolic blood pressure.

data from two 12-week empagliflozin dose-ranging studies and a 24-week Phase III study of the two approved empagliflozin doses (10 and $25 \mathrm{mg}$ ) demonstrated that empagliflozin monotherapy was associated with improvements in the concentration of glycated hemoglobin $\left(\mathrm{HbA}_{1 \mathrm{c}}\right)$, with mean reductions of up to $-0.78 \%$ (Table 1 ). ${ }^{15-17}$ These improvements were accompanied by reductions in fasting plasma glucose (FPG) as well as by modest reductions in bodyweight and systolic BP. The incidence of hypoglycemia and of urinary tract infection (UTI) was similar to that observed with placebo, but there was an increased risk of genital infection (Table 2). For example, in the 24-week Phase III study, none of the patients in the placebo group reported genital infections during the trial compared with $3 \%$ of the empagliflozin $10 \mathrm{mg}$ group and $4 \%$ of the empagliflozin $25 \mathrm{mg}$ group. ${ }^{15}$

\section{Empagliflozin combination therapy with other oral glucose-lowering agents}

As SGLT2 inhibitors have a novel and noninsulin-dependent mechanism of action, empagliflozin could potentially be used in combination with any class of glucose-lowering agents. To date, clinical trials evaluating empagliflozin in combination with metformin, pioglitazone, sulfonylurea, linagliptin, and insulin have been published: Tables 3 and 4 show key efficacy and safety data from these studies. ${ }^{18-30}$

\section{Empagliflozin-metformin combination therapy}

As metformin is the recommended first-line glucose-lowering agent in patients with $\mathrm{T} 2 \mathrm{DM},{ }^{31}$ it is an obvious choice for empagliflozin combination therapy. In a Phase II dose-ranging study, empagliflozin as add-on to metformin gave significant reductions in $\mathrm{HbA}_{1 \mathrm{c}}$ versus placebo for all doses tested except the $1 \mathrm{mg}$ dose. ${ }^{18}$ In a Phase III placebo-controlled trial, after 24 weeks, treatment with empagliflozin (10 and $25 \mathrm{mg}$ ) plus metformin provided significant reductions in $\mathrm{HbA}_{1 \mathrm{l}}$, bodyweight, and BP - both systolic and diastolic - versus placebo plus metformin (Table 3) ${ }^{19}$ Very few patients had confirmed hypoglycemic adverse events (AEs; defined as plasma glucose $\leq 70 \mathrm{mg} / \mathrm{dL}$ and/or requiring assistance), but these were more common in the empagliflozin groups $(0.5 \%, 1.8 \%$, and $1.4 \%$ of placebo, empagliflozin $10 \mathrm{mg}$, and empagliflozin $25 \mathrm{mg}$ groups, respectively); none of the patients required assistance. ${ }^{19}$ Events consistent with UTI occurred in a similar proportion of patients receiving placebo or empagliflozin, and events consistent with genital infection were more common in the empagliflozin groups (Table 4). ${ }^{19}$

In a 2-year, head-to-head study of empagliflozin $(25 \mathrm{mg})$ versus glimepiride ( $1-4 \mathrm{mg}$ once daily; mean dose $2.7 \mathrm{mg} / \mathrm{d}$ ) in patients on stable metformin, patients treated with empagliflozin had greater improvements in glucose control. ${ }^{20} \mathrm{At}$ 52 weeks, mean reductions in $\mathrm{HbA}_{1 \mathrm{c}}$ were $-0.73 \%$ for the 
Table 2 Empagliflozin monotherapy studies: key safety data

\begin{tabular}{|c|c|c|c|c|c|c|c|c|}
\hline \multirow[t]{2}{*}{ Study } & \multirow[t]{2}{*}{ Study details } & \multirow[t]{2}{*}{$\begin{array}{l}\text { Regimen } \\
\text { details }\end{array}$} & \multirow[t]{2}{*}{$\mathbf{N}$} & \multirow{2}{*}{$\begin{array}{l}\text { Treatment } \\
\text { and dose } \\
(\mathrm{mg} / \mathrm{d})\end{array}$} & \multicolumn{4}{|c|}{$\begin{array}{l}\text { Safety parameters (number and percentage of patients with a special } \\
\text { interest adverse event) }\end{array}$} \\
\hline & & & & & $\begin{array}{l}\text { Hypoglycemia, } \\
\text { n (\%) }\end{array}$ & $\begin{array}{l}\text { Urinary tract infection, } \\
n(\%) \text { [males and } \\
\text { females, } n(\%) \\
\text { if stated] }\end{array}$ & $\begin{array}{l}\text { Genital infection, } \\
n \text { (\%) [males and } \\
\text { females, } \mathbf{n}(\%) \\
\text { if stated] }\end{array}$ & $\begin{array}{l}\text { Volume } \\
\text { depletion, } \\
\text { n (\%) }\end{array}$ \\
\hline \multirow[t]{5}{*}{$\begin{array}{l}\text { Roden } \\
\text { et } \mathrm{al}^{15}\end{array}$} & Phase III, 24 wk & Monotherapy & 228 & Pbo & $\mathrm{I}(<\mathrm{I})$ & $\begin{array}{l}\text { I2 (5) } \\
{[M 3 / / 24(2), F 9 / 105(9)]}\end{array}$ & $\begin{array}{l}0 \\
{[\mathrm{MO} / / 24, \mathrm{FO} / \mathrm{I05}]}\end{array}$ & $\begin{array}{l}\text { Not } \\
\text { reported }\end{array}$ \\
\hline & & & 224 & EMPA 10 & $\mathrm{I}(<\mathrm{I})$ & $\begin{array}{l}\text { I5 (7) } \\
{[M 3 / / 42(2), F I 2 / 82(15)]}\end{array}$ & $\begin{array}{l}7(3) \\
{[M 4 / / 42(3), F 3 / 82} \\
(4)]\end{array}$ & $\begin{array}{l}\text { Not } \\
\text { reported }\end{array}$ \\
\hline & & & 224 & EMPA 25 & $\mathrm{I}(<\mathrm{I})$ & $\begin{array}{l}\text { I2 (5) } \\
\text { [M2/I44 (I), FIO/79 (I3)] }\end{array}$ & $\begin{array}{l}9(4) \\
{[M 2 / / 44(I), F 7 / 79} \\
(9)]\end{array}$ & $\begin{array}{l}\text { Not } \\
\text { reported }\end{array}$ \\
\hline & & & 223 & SITA 100 & $\mathrm{I}(<\mathrm{I})$ & $\begin{array}{l}\text { II (5) } \\
{[M 4 / I 4 \text { I (3), F7/82 (9)] }}\end{array}$ & $\begin{array}{l}2(\mathrm{I}) \\
{[\mathrm{MI} / \mathrm{II}(\mathrm{I}), \mathrm{FI} / 82} \\
(\mathrm{I})]\end{array}$ & $\begin{array}{l}\text { Not } \\
\text { reported }\end{array}$ \\
\hline & & & 87 & $\begin{array}{l}\text { EMPA } 25 \\
\left(\mathrm{HbA}_{\mathrm{Ic}}>10.0 \%\right)\end{array}$ & 0 & $\begin{array}{l}3(3) \\
{[M 2 / 64(3), F I / 23(4)]}\end{array}$ & $\begin{array}{l}\mathrm{I}(\mathrm{I}) \\
{[\mathrm{MI} / 64(2), \mathrm{F} 0 / 23]}\end{array}$ & $\begin{array}{l}\text { Not } \\
\text { reported }\end{array}$ \\
\hline \multirow[t]{5}{*}{$\begin{array}{l}\text { Ferrannini } \\
\text { et } \mathrm{al}^{16}\end{array}$} & Phase II, I2 wk & Monotherapy & 82 & Pbo & I (I.2) & $\mathrm{I}(\mathrm{I} .2)$ & 0 & $\begin{array}{l}\text { Not } \\
\text { reported }\end{array}$ \\
\hline & & & 81 & EMPA 5 & 0 & $2(2.5)$ & 0 & $\begin{array}{l}\text { Not } \\
\text { reported }\end{array}$ \\
\hline & & & 81 & EMPA I0 & 0 & I (I.2) & $3(3.7)$ & $\begin{array}{l}\text { Not } \\
\text { reported }\end{array}$ \\
\hline & & & 82 & EMPA 25 & 0 & I (I.2) & $2(2.4)$ & $\begin{array}{l}\text { Not } \\
\text { reported }\end{array}$ \\
\hline & & & 80 & MET (O/L) & I (I.2) & $2(2.5)$ & 0 & $\begin{array}{l}\text { Not } \\
\text { reported }\end{array}$ \\
\hline \multirow[t]{5}{*}{$\begin{array}{l}\text { Kadowaki } \\
\text { et } \text { al }^{17}\end{array}$} & Phase II, I2 wk & Monotherapy & 109 & Pbo & 0 & $\begin{array}{l}\text { I }(0.9) \\
{[\mathrm{MI} / 80(\mathrm{I} .3), \mathrm{F} 0 / 29]}\end{array}$ & $\begin{array}{l}0 \\
{[\mathrm{M} 0 / 80, \mathrm{~F} 0 / 29]}\end{array}$ & I (0.9) \\
\hline & & & 110 & EMPA 5 & 0 & $\begin{array}{l}0 \\
{[\mathrm{M} 0 / 84, \mathrm{~F} 0 / 26]}\end{array}$ & $\begin{array}{l}\text { I }(0.9) \\
{[\mathrm{MI} / 84(\mathrm{I} .2), \mathrm{FO} / 26]}\end{array}$ & 0 \\
\hline & & & 109 & EMPA 10 & 0 & $\begin{array}{l}\mathrm{I}(0.9) \\
{[\mathrm{MI} / 77(\mathrm{I} .3), \mathrm{F} 0 / 32]}\end{array}$ & $\begin{array}{l}\mathrm{I}(0.9) \\
{[\mathrm{MI} / 77(\mathrm{I} .3), \mathrm{F} 0 / 32]}\end{array}$ & I (0.9) \\
\hline & & & 109 & EMPA 25 & I (0.9) & $\begin{array}{l}\mathrm{I}(0.9) \\
{[\mathrm{M} 0 / 84, \mathrm{FI} / 25(4.0)]}\end{array}$ & $\begin{array}{l}0 \\
{[\mathrm{MO} / 84, \mathrm{~F} 0 / 25]}\end{array}$ & $\mathrm{I}(0.9)$ \\
\hline & & & 110 & EMPA 50 & I (0.9) & $\begin{array}{l}\mathrm{I}(0.9) \\
{[\mathrm{M} 0 / 85, \mathrm{FI} / 25(4.0)]}\end{array}$ & $\begin{array}{l}\text { I }(0.9) \\
{[\mathrm{MI} / 85(\mathrm{I} .2), \mathrm{F} 0 / 25]}\end{array}$ & 0 \\
\hline
\end{tabular}

Note: Number of male and female patients in the safety set was not available for all studies; in those cases only percentages are shown. MET dosing: I000 mg/d for 4 weeks, thereafter increased to $1000 \mathrm{mg}$ twice daily, or up to maximum tolerated dose, if needed.

Abbreviations: EMPA, empagliflozin; F, female; $\mathrm{HbA}_{\mathrm{Ic}}$, glycated hemoglobin; M, male; MET, metformin; O/L, open label; Pbo, placebo.

empagliflozin $25 \mathrm{mg}$ group and $-0.66 \%$ for the glimepiride (1-4 mg group; at 104 weeks), mean reductions were $-0.66 \%$ and $-0.55 \%$ for the respective groups. Significant reductions in bodyweight were observed with empagliflozin versus an increase with glimepiride (Table 3). ${ }^{20}$ Confirmed hypoglycemic AEs were more frequent in patients treated with glimepiride versus empagliflozin. ${ }^{20}$ The proportion of patients with events consistent with UTI was similar in both groups; however, events consistent with genital infection occurred in a higher proportion of the empagliflozin group (Table 4). ${ }^{20}$

Lastly, a comparison of empagliflozin twice-daily (12.5 and $5 \mathrm{mg}$ ) and once-daily (25 and $10 \mathrm{mg}$ ) regimens, all versus placebo, in patients on stable metformin revealed similar therapeutic effects and tolerability of both regimens, confirming the potential for empagliflozin to be given as single-pill combination with metformin immediate-release (Table 3 ). ${ }^{29}$

\section{Empagliflozin-DPP-4 inhibitor combination therapy}

Dipeptidyl peptidase-4 (DPP-4) inhibitors are a commonly used second-line option for T2DM, having the advantages of well-established tolerability with no increased risk of hypoglycemia and being bodyweight-neutral. ${ }^{31}$ Empagliflozin has been studied as a single-pill combination with linagliptin 


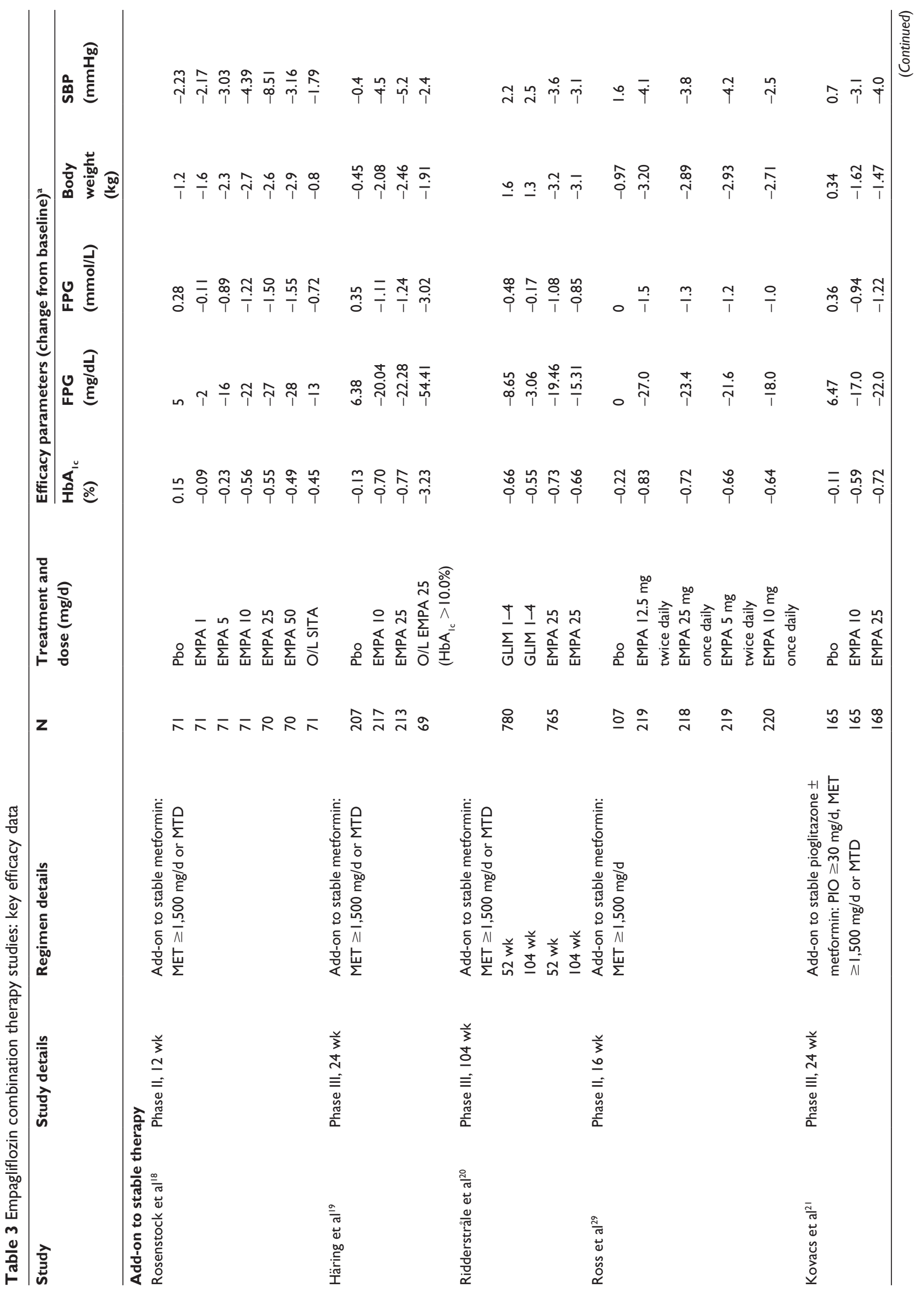




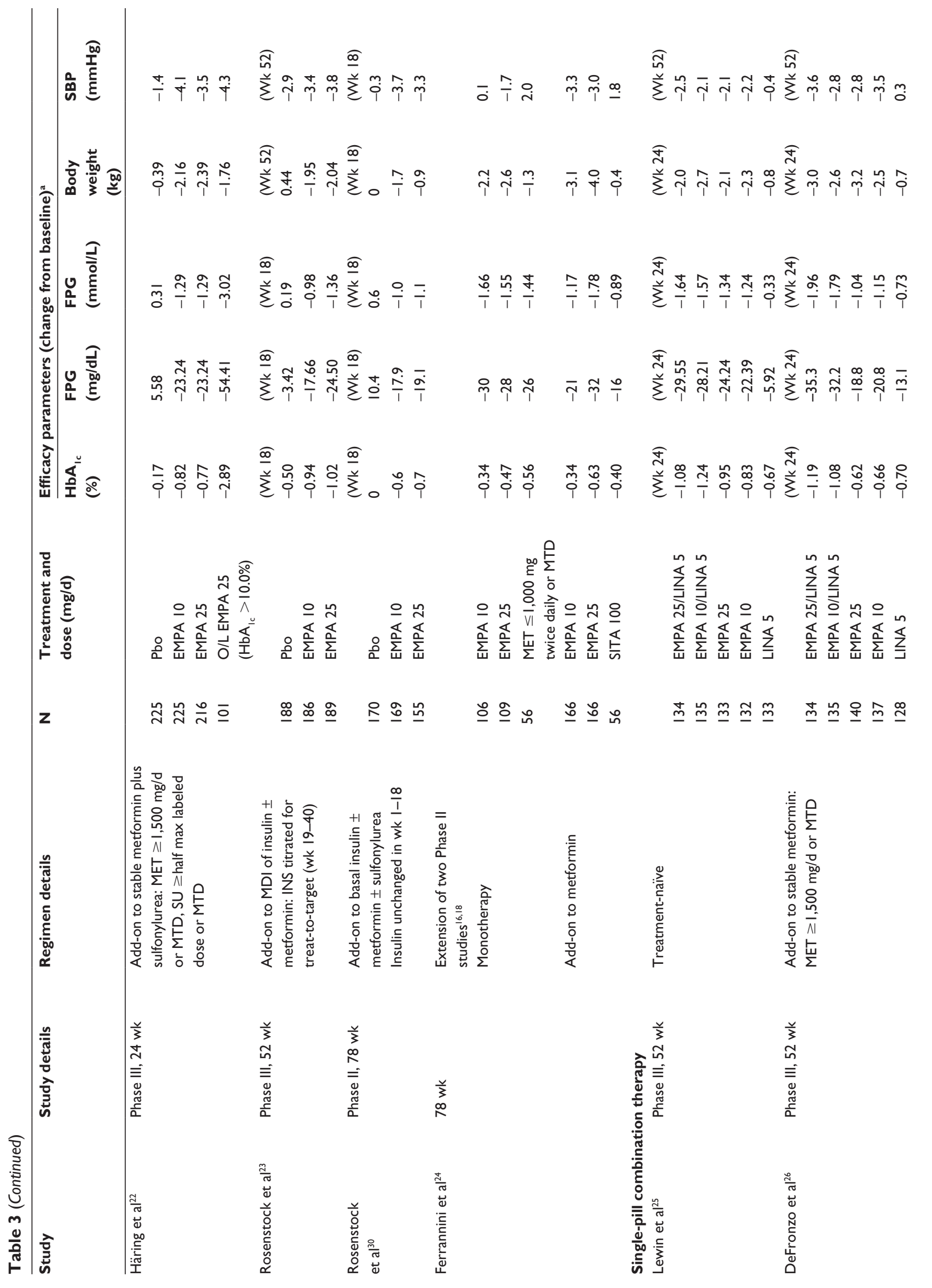




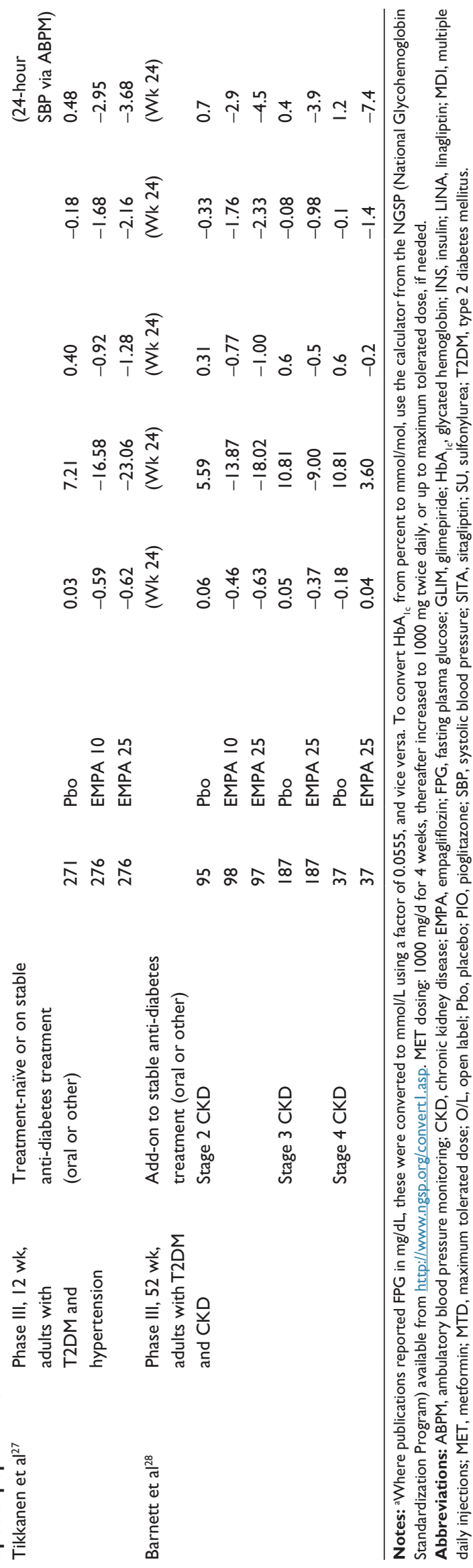

in treatment-naïve patients ${ }^{25}$ and as an add-on to stable metformin; ${ }^{26}$ both studies compared the single-pill combination with the individual components.

In the treatment-naïve patients, $\mathrm{HbA}_{1 \mathrm{c}}$ reductions after 24 weeks were significantly greater for the empagliflozin $25 \mathrm{mg} /$ linagliptin $5 \mathrm{mg}$ single-pill formulation than linagliptin $5 \mathrm{mg}(P<0.001)$ but not compared with empagliflozin $25 \mathrm{mg}(P=0.179)$, and were significantly greater for the empagliflozin $10 \mathrm{mg} /$ linagliptin $5 \mathrm{mg}$ single-pill formulation compared with the individual components $(P<0.001$ for both). ${ }^{25}$ The proportion of patients with a baseline $\mathrm{HbA}_{1 \mathrm{c}}$ $\geq 7 \%$ who had reached $\mathrm{HbA}_{1 \mathrm{c}}<7 \%$ at week 24 was greater for empagliflozin/linagliptin groups $(55.4 \%, 62.3 \%, 41.5 \%$, $38.8 \%$, and $32.3 \%$ for empagliflozin $25 \mathrm{mg} /$ linagliptin $5 \mathrm{mg}$, empagliflozin $10 \mathrm{mg} /$ linagliptin $5 \mathrm{mg}$, empagliflozin $25 \mathrm{mg}$, empagliflozin $10 \mathrm{mg}$, and linagliptin $5 \mathrm{mg}$, respectively). ${ }^{25}$ The proportion of patients reporting AEs was similar across treatment groups, and there were no confirmed hypoglycemic events requiring assistance. ${ }^{25}$

Similar results were reported in the add-on to stable metformin study; however, reductions in $\mathrm{HbA}_{1 \mathrm{c}}$ at week 24 were significantly greater for both the empagliflozin/linagliptin doses compared with the individual components $(P<0.001$ for each). ${ }^{26}$ In both of these studies, $\mathrm{HbA}_{1 \mathrm{c}}$ reductions with empagliflozin/linagliptin were sustained at week 52. ${ }^{25,26}$ Furthermore, both studies demonstrated that reductions in bodyweight from baseline to week 52 were significantly greater with empagliflozin/linagliptin compared with linagliptin, but not significantly different compared with the respective empagliflozin components. ${ }^{25,26}$

\section{Empagliflozin-pioglitazone combination therapy}

Pioglitazone is one of the options recommended by the American Diabetes Association/European Association for the Study of Diabetes (ADA/EASD) guidelines for secondline therapy, ${ }^{32}$ or as an alternative first-line therapy when metformin is not tolerated. It has the advantages of improving insulin resistance, low hypoglycemia risk, and generic options/costs; but is commonly associated with peripheral edema and weight gain, as well as less frequently with congestive heart failure and bone fractures, ${ }^{33}$ and a possible increased risk of bladder cancer. ${ }^{33,34}$ Since safety concerns were raised, use of pioglitazone has fallen to about half the previous levels, although this is still several million prescriptions per year in the US alone. ${ }^{35}$

In a 24-week study of empagliflozin as an add-on to pioglitazone (approximately $75 \%$ of patients also received 


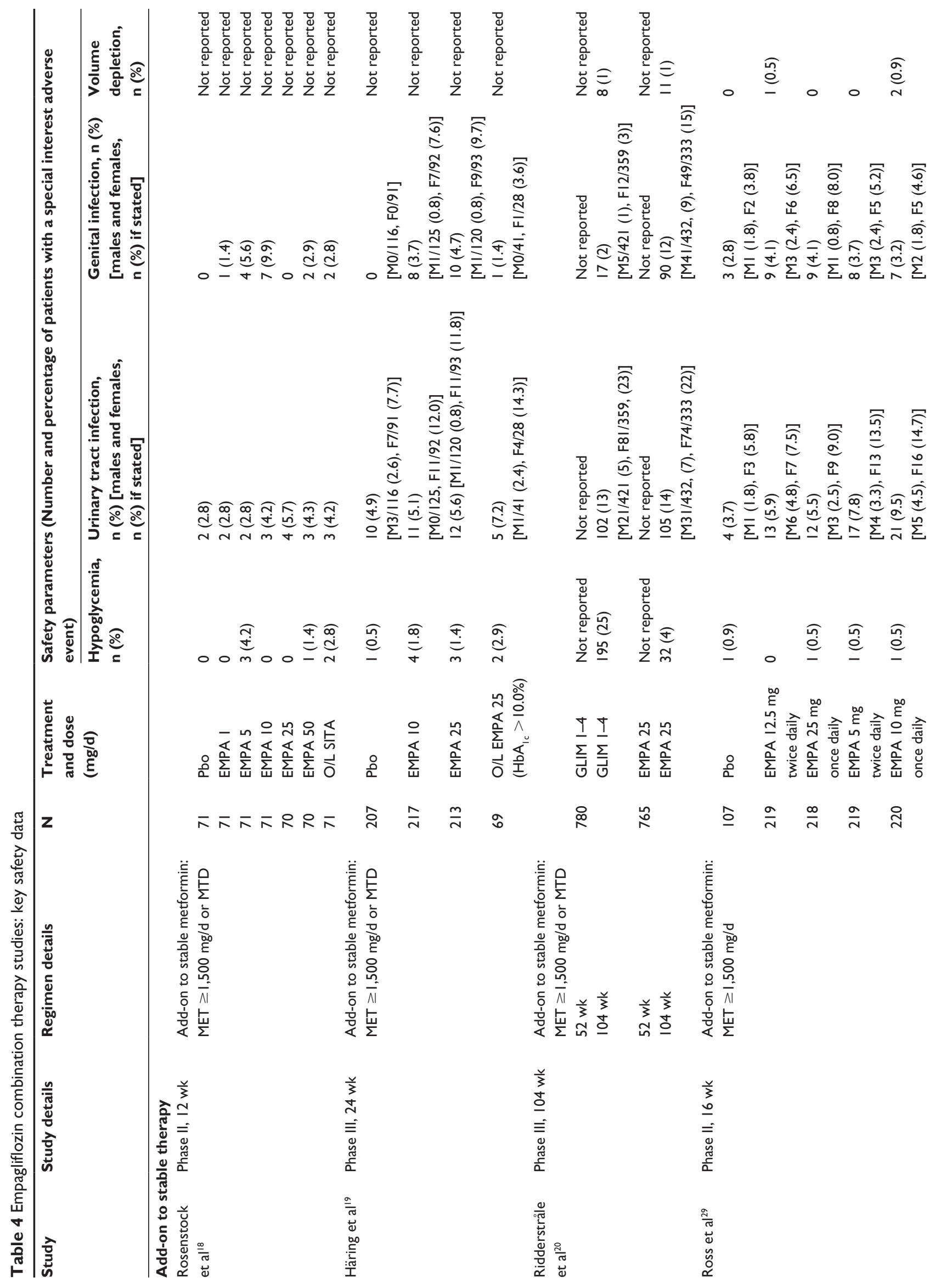




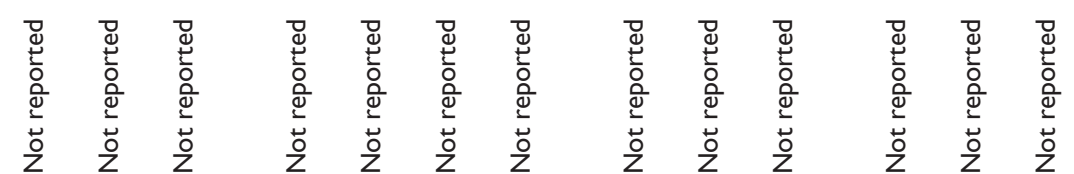

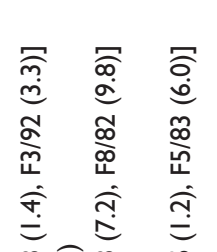

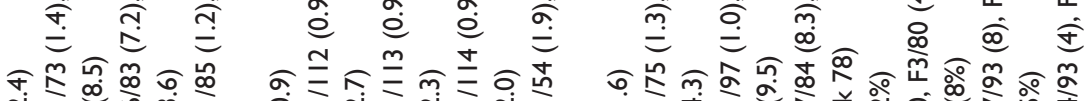

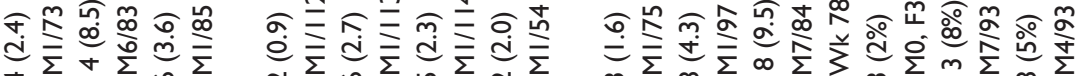

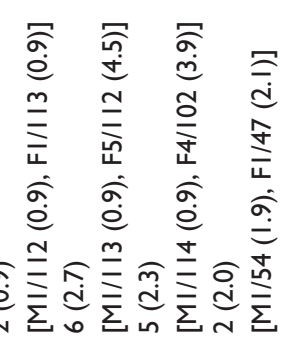

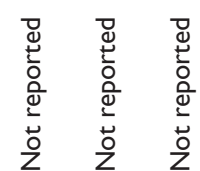

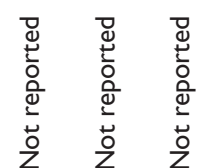

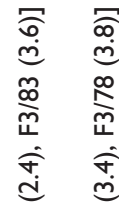

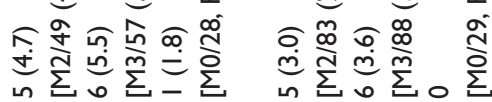

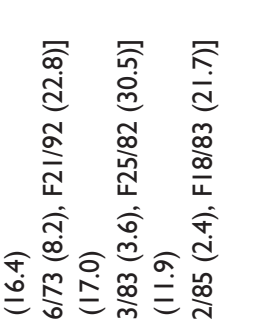

స $\sum_{i}^{\infty} \sum_{i}^{\infty} \sum_{i}^{\infty}$
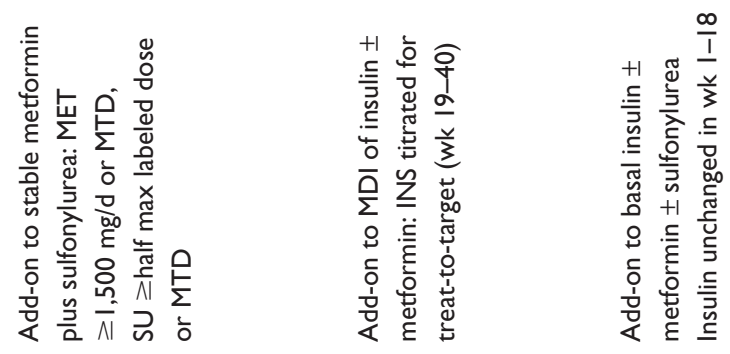

으 으 


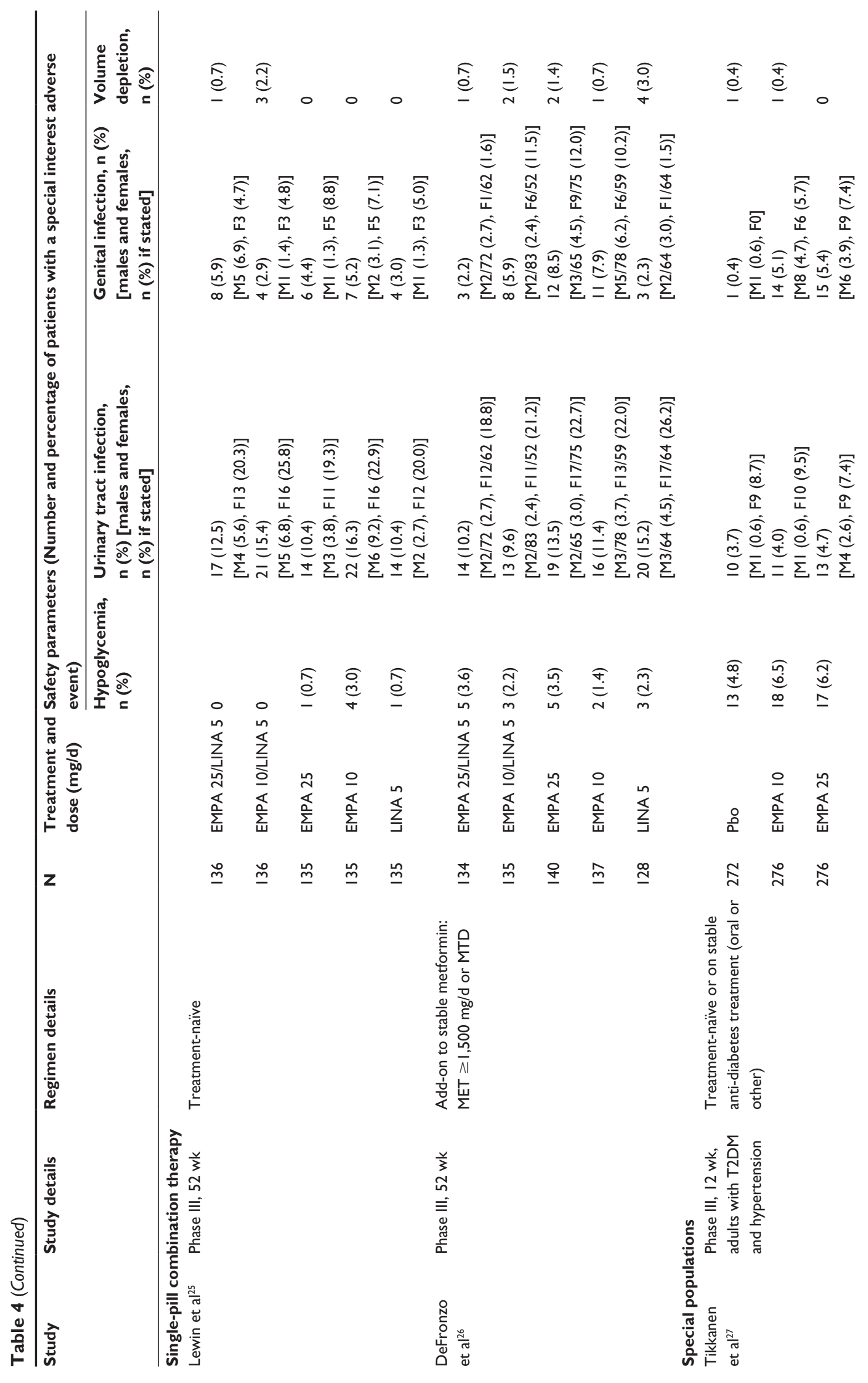



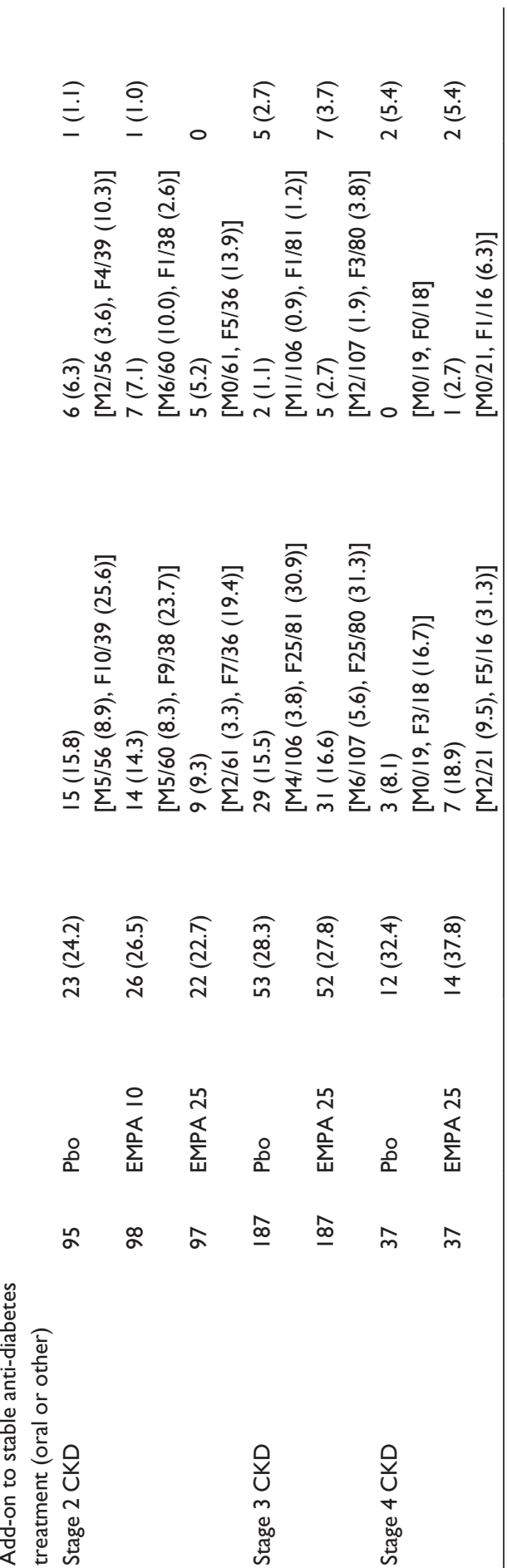

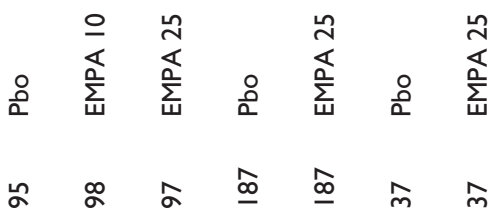

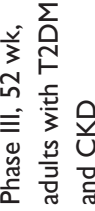

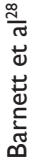

metformin), empagliflozin led to significant reductions in $\mathrm{HbA}_{1 \mathrm{c}}$ versus placebo, with reductions of $-0.59 \%$ and $-0.72 \%$ in the empagliflozin 10 and $25 \mathrm{mg}$ groups versus $-0.11 \%$ in the placebo group (Table 3 ). ${ }^{21}$ Similarly significant reductions were observed in FPG, bodyweight, systolic BP, and diastolic BP for empagliflozin versus placebo groups. ${ }^{21}$ The frequency of hypoglycemia events was low, and none required assistance. ${ }^{21}$ The authors reported that the proportion of patients with AEs consistent with UTI was unexpectedly high in all treatment groups $(12 \%-17 \%)$ and hypothesized it may have resulted from ascertainment bias at the study centers. ${ }^{21}$ There was no increased frequency of AEs typically associated with pioglitazone, such as edema, heart failure, and bone fracture. ${ }^{21}$

\section{Empagliflozin-sulfonylurea combination therapy}

The efficacy of sulfonylureas in glucose-lowering is well known, as are their unwanted effects (weight gain, hypoglycemia risk). Although no longer in favor with many clinicians, sulfonylureas are still widely prescribed due to the associated extensive experience in terms of patient-years and their low cost.

Empagliflozin as add-on to sulfonylureas plus metformin in a 24-week study significantly improved glucose control, bodyweight, and systolic BP versus placebo (Table 3). ${ }^{22}$ Mean reductions in $\mathrm{HbA}_{1 \mathrm{c}}$ were of a similar order to those seen when empagliflozin was added to metformin $(-0.82 \%$ with empagliflozin $10 \mathrm{mg},-0.77 \%$ with empagliflozin $25 \mathrm{mg}$, and -0.17 with placebo). Hypoglycemia events were more common with empagliflozin than placebo (Table 4), although none of these events required assistance. ${ }^{22}$ As sulfonylureas raise insulin levels irrespective of glucose concentration, which increases the risk of hypoglycemia, it may be expected that empagliflozinsulfonylurea combination therapy would increase the risk of hypoglycemic events, which is reflected in empagliflozin labeling information. ${ }^{6}$

\section{Empagliflozin combination therapy with injected agents}

Many patients with advanced T2DM require treatment with insulin to maintain glycemic control, progressing from basal insulin to prandial dosing, and then to multiple daily injections. ${ }^{31}$ Combining insulin with oral glucose-lowering agents can help to reduce daily insulin requirements, ${ }^{31}$ which may reduce weight gain and the hypoglycemia risk associated with insulin therapy. 
In a 78-week study, empagliflozin 10 or $25 \mathrm{mg}$ in combination with basal insulin gave significant reductions in $\mathrm{HbA}_{1 \mathrm{c}}$ and FPG, and significant improvements in bodyweight and systolic BP (Table 3).$^{30}$ During the first 18 weeks, when the insulin dose was kept constant, $\mathrm{HbA}_{1 \mathrm{c}}$ levels were unchanged in the placebo group (mean change, $0 \%$ ) compared with reductions of $-0.6 \%$ and $-0.7 \%$ in the empagliflozin 10 and $25 \mathrm{mg}$ groups, respectively. After week 18, the insulin dose was adjusted at the investigator's discretion for any confirmed FPG $>110 \mathrm{mg} / \mathrm{dL}$; patients could also be on background metformin and/or a sulfonylurea, which remained unchanged. At week 78, although titration was not systematically required, mean insulin dose (a key secondary end point) was significantly reduced in both empagliflozin groups versus an increase with placebo (adjusted mean \pm standard error [SE] changes from baseline: $5.5 \pm 1.6,-1.2 \pm 1.5$, and $-0.5 \pm 1.6 \mathrm{IU}$ with placebo, empagliflozin $10 \mathrm{mg}$, and empagliflozin $25 \mathrm{mg}$, respectively; $P=0.002$ and $P=0.009$ for empagliflozin 10 and $25 \mathrm{mg}$, respectively, versus placebo). Rates of hypoglycemia were similar across all treatment groups (Table 4). Genital infections occurred more frequently in the empagliflozin groups, being reported in $2 \%$ of the placebo group (with no infections reported in males), $8 \%$ of the empagliflozin $10 \mathrm{mg}$ group, and 5\% of the empagliflozin $25 \mathrm{mg}$ group (Table 4).

In a 52-week study of T2DM patients inadequately controlled on multiple daily injections of insulin (with or without metformin), empagliflozin 10 and $25 \mathrm{mg}$ improved glucose control and reduced bodyweight versus placebo (Table 3 ). ${ }^{23}$ Insulin dose was to remain stable during weeks 1-18, and, at week 18, mean reductions in $\mathrm{HbA}_{1 \mathrm{c}}$ were $-0.94 \%$ with empagliflozin $10 \mathrm{mg},-1.02 \%$ with empagliflozin $25 \mathrm{mg}$, and $-0.50 \%$ with placebo. Subsequently, insulin doses were to be adjusted to glucose targets in weeks 19-40 (preprandial glucose $<5.5 \mathrm{mmol} / \mathrm{L}[<100 \mathrm{mg} / \mathrm{dL}]$; postprandial glucose $<7.8 \mathrm{mmol} / \mathrm{L}[<140 \mathrm{mg} / \mathrm{dL}]$ ), and then stable in weeks 41-52. After 52 weeks, the secondary end point of mean insulin dose was reduced in both empagliflozin groups versus placebo (adjusted mean difference in insulin dose from baseline to week 52 versus placebo: $-8.8 \mathrm{IU} / \mathrm{d}$ [95\% CI, -14.8 to -2.8 ] for empagliflozin $10 \mathrm{mg}, P=0.004$; and $-11.2 \mathrm{IU} / \mathrm{d}$ [95\% CI, -17.2 to -5.2 ] for empagliflozin $25 \mathrm{mg}, P<0.001) .{ }^{23}$ The proportion of patients with confirmed hypoglycemia was similar across all treatment groups (Table 4). Severe hypoglycemia (requiring assistance) occurred in three patients each in the placebo and empagliflozin $10 \mathrm{mg}$ groups, and also in one patient in the empagliflozin $25 \mathrm{mg}$ group. ${ }^{23}$ Urinary tract infections were reported in similar proportions of patients (Table 4), while genital infections were more common in both empagliflozin groups than in the placebo group (Table 4).

Besides insulin, glucagon-like peptide-1 (GLP-1) receptor agonists (RAs) are also commonly used injected glucoselowering agents in T2DM. A combination of an SGLT2 inhibitor and a GLP-1 RA would be ideal in many respects, particularly regarding the potential combined weight loss. To date, no clinical trial results of SGLT2 inhibitors in combination with a GLP-1 RA have been published, although one such trial is known to be underway, assessing the combination of canagliflozin and liraglutide (ClinicalTrials.gov identifier: NCT02324842). Preliminary reports indicate that clinicians are trying the SGLT2 inhibitor/GLP-1 RA combination in clinical practice, and suggest additional weight loss is typically observed, although the study sizes have been fairly small..$^{36,37}$

\section{Achieving target $\mathrm{HbA}_{\mathrm{lc}}<7.0 \%$}

According to current ADA guidelines, lowering $\mathrm{HbA}_{1 \mathrm{c}}$ to $<7.0 \%$ is associated with reductions in microvascular complications of diabetes, and also macrovascular disease (if implemented promptly in newly-diagnosed patients); therefore, $\mathrm{HbA}_{1 \mathrm{c}}<7.0 \%$ is considered a reasonable target in many nonpregnant adults. ${ }^{38}$ Consequently, studies often measure the percentage of patients with baseline $\mathrm{HbA}_{1 \mathrm{c}} \geq 7.0 \%$ who have $\mathrm{HbA}_{1 \mathrm{c}}$ reduced to $<7.0 \%$ at the end of treatment, even though comparison between studies is questionable, as a patient's baseline $\mathrm{HbA}_{1 \mathrm{c}}$ is a correlate of the likelihood of achieving the target $\mathrm{HbA}_{1 \mathrm{c}} \cdot{ }^{39,40}$

Table 5 summarizes these data for 24-week clinical trials evaluating empagliflozin versus placebo. More patients with baseline $\mathrm{HbA}_{1 \mathrm{c}} \geq 7.0 \%$ (mean baseline $\mathrm{HbA}_{1 \mathrm{c}}$ approximately $7.9 \%$ ) achieved $\mathrm{HbA}_{1 \mathrm{c}}<7.0 \%$ at week 24 with empagliflozin monotherapy (10 or $25 \mathrm{mg}$ ) than with placebo (35\% and 44\% versus $12 \%$, respectively), while $28 \%$ of patients receiving sitagliptin $100 \mathrm{mg}$ similarly achieved $\mathrm{HbA}_{1 \mathrm{c}}<7.0 \%{ }^{15}$ A smaller proportion of patients with very poor glycemic control (mean baseline $\mathrm{HbA}_{1 \mathrm{c}} 11.5 \%$ ) achieved $\mathrm{HbA}_{1 \mathrm{c}}<7.0 \%$ at week 24 with empagliflozin $25 \mathrm{mg}$ ( $28 \%$; open-label study). A similar trend was observed in studies of empagliflozin in combination with metformin, pioglitazone, and a sulfonylurea. ${ }^{19,21,22,28}$ In the 104-week study of empagliflozin versus glimepiride, both as add-on to metformin, the proportion of patients achieving $\mathrm{HbA}_{1 \mathrm{c}}<7.0 \%$ at week 104 was similar between groups (empagliflozin 34\%; glimepiride 31\%). ${ }^{20}$ However, the authors commented that significantly fewer patients received rescue therapy on empagliflozin (14.8\%) than on glimepiride (23.7\%; odds ratio, 0.530 [95\% CI, 0.404, 0.696]; $P<0.0001) .{ }^{20}$ 
Table 5 Patients with T2DM and $\mathrm{HbA}_{\mathrm{lc}} \geq 7.0 \%$ at baseline who reached $\mathrm{HbA}_{\mathrm{lc}}<7.0 \%$ at end of treatment period: data from $24-$ week placebo-controlled empagliflozin trials

\begin{tabular}{|c|c|c|c|c|c|c|}
\hline Study & $\begin{array}{l}\text { Study } \\
\text { duration } \\
\text { (wk) }\end{array}$ & $\begin{array}{l}\text { EMPA regimen and } \\
\text { background therapy }\end{array}$ & $\mathbf{N}$ & $\begin{array}{l}\text { Treatment and } \\
\text { dose }(\mathrm{mg} / \mathrm{d})\end{array}$ & $\begin{array}{l}\text { Mean } \\
\text { baseline } \\
\text { HbA }_{\text {Ic }}(\%)\end{array}$ & $\begin{array}{l}\text { Patients with } \\
\text { HbA }_{\mathrm{lc}}<7.0 \%, \\
\text { n (\%) }\end{array}$ \\
\hline \multirow[t]{6}{*}{ Roden et $\mathrm{al}^{15}$} & 24 & Monotherapy in treatment naïve & 228 & Pbo & 7.91 & $25 / 208(12)$ \\
\hline & & patients & 224 & EMPA 10 & 7.87 & $72 / 204(35)$ \\
\hline & & & 224 & EMPA 25 & 7.86 & $88 / 202(44)$ \\
\hline & & & 223 & SITA 100 & 7.85 & $75 / 200(38)$ \\
\hline & & & 87 & O/L EMPA 25 & 11.50 & $24 / 87(28)$ \\
\hline & & & & $\left(\mathrm{HbA}_{\mathrm{Ic}}>10.0 \%\right)$ & & \\
\hline \multirow[t]{5}{*}{ Häring et al ${ }^{19}$} & 24 & Add-on to stable metformin & 207 & Pbo & 7.90 & $23(12.5)$ \\
\hline & & $(\geq \mathrm{I}, 500 \mathrm{mg} / \mathrm{d}$ or MTD or MDLL) & 217 & EMPA 10 & 7.94 & $75(37.7)$ \\
\hline & & & 213 & EMPA 25 & 7.86 & $74(38.7)$ \\
\hline & & & 69 & O/L EMPA 25 & 11.07 & $6(8.7)$ \\
\hline & & & & $\left(\mathrm{HbA}_{\mathrm{lc}}>10.0 \%\right)$ & & \\
\hline \multirow[t]{3}{*}{ Kovacs et $\mathrm{al}^{21}$} & 24 & Add-on to stable pioglitazone & 165 & Pbo & 8.2 & $12(7.7)$ \\
\hline & & $(\geq 30 \mathrm{mg} / \mathrm{d}) \pm$ metformin & 165 & EMPA 10 & 8.1 & $36(23.8)$ \\
\hline & & $(\geq \mathrm{I}, 500 \mathrm{mg} / \mathrm{d}$ or MTD) & 168 & EMPA 25 & 8.1 & $48(30.0)$ \\
\hline \multirow[t]{5}{*}{ Häring et $\mathrm{al}^{22}$} & 24 & Add-on to stable metformin & 225 & Pbo & 8.15 & $20(9.3)$ \\
\hline & & $(\geq \mathrm{I}, 500 \mathrm{mg} / \mathrm{d}$ or MTD) plus & 225 & EMPA 10 & 8.07 & $55(26.3)$ \\
\hline & & sulfonylurea ( $\geq$ half-max labeled & 216 & EMPA 25 & 8.10 & $65(32.2)$ \\
\hline & & dose or MTD) & 101 & O/L EMPA 25 & 11.18 & $9(8.9)$ \\
\hline & & & & $\left(\mathrm{HbA}_{\mathrm{Ic}}>10.0 \%\right)$ & & \\
\hline
\end{tabular}

Note: aPatients with $\mathrm{HbA}_{1 \mathrm{c}} \geq 7.0 \%$ at baseline who reached $\mathrm{HbA}_{\mathrm{lc}}<7.0 \%$ at end of treatment period.

Abbreviations: EMPA, empagliflozin; $\mathrm{HbA}_{\mathrm{Ic}}$, glycated hemoglobin; MDLL, maximum dose per local label; MTD, maximum tolerated dose; O/L, open label; Pbo, placebo; SITA, sitagliptin; T2DM, type 2 diabetes mellitus.

\section{Discussion: a patient-centered approach - how could it work in practice? Overweight and obese patients}

The impact of medications on bodyweight is a key consideration in $\mathrm{T} 2 \mathrm{DM} .{ }^{41}$ While the impact of weight loss on the risk of cardiovascular events has not been definitively proven, its importance is well established for other factors, such as mobility or quality of life. ${ }^{42}$ In empagliflozin clinical studies, modest reductions in bodyweight of approximately $2-5 \mathrm{~kg}$ (5-10 pounds) were reported. Furthermore, imaging studies confirmed that $90 \%$ of the weight loss observed with empagliflozin was due to decreased fat mass, with reduction in abdominal visceral adipose tissue and abdominal subcutaneous adipose tissue. ${ }^{20}$ This is comparable to the weight loss observed with metformin or GLP-1 RAs of approximately $3 \mathrm{~kg}$ (6 pounds). ${ }^{43,44}$ As already mentioned, DPP-4 inhibitors are weight-neutral, while sulfonylureas, insulin, and thiazolidinediones are associated with weight gain.

As effective therapies for weight loss are limited, clinicians recognize the value of additional weight loss from glucose-lowering agents. For example, although offlabel, metformin has been used for weight loss, ${ }^{45}$ and the GLP-1 RA, liraglutide, was approved for use in chronic weight management. ${ }^{46,47}$ For obese patients motivated to lose weight, the combination of metformin, GLP-1 RA, and SGLT2 inhibitor is worth considering. In addition, as mentioned, adding empagliflozin in patients with T2DM who require insulin may help to offset insulin-associated weight gain.

\section{Patients with renal impairment}

Renal impairment is common in patients with T2DM. ${ }^{48}$ Patients with advanced renal impairment are a difficult-totreat population due to the presence of associated comorbidities, reduced drug elimination, and an increased risk of hypoglycemia. ${ }^{49}$

Empagliflozin is contraindicated in patients with severe or end-stage renal disease (and would not be expected to have efficacy in these groups), but has been studied in patients with chronic kidney disease (CKD) ${ }^{28}$ In a 52-week study of patients with T2DM and stage 2, 3, or 4 CKD (defined as estimated glomerular filtration rate $[\mathrm{eGFR}] \geq 60$ to $<90$, $\geq 30$ to $<60$, or $\geq 15$ to $<30 \mathrm{~mL} / \mathrm{min} / 1.73 \mathrm{~m}^{2}$ for stage 2 , 3 , and 4 , respectively), empagliflozin treatment resulted in significant reductions in $\mathrm{HbA}_{1 \mathrm{c}}$ versus placebo, accompanied by improvements in weight and BP. ${ }^{28}$ Empagliflozin was well tolerated; however, each CKD group had small decreases 
in eGFR, which returned to baseline levels after the end of treatment (during a 3 -week follow-up period). ${ }^{28}$

\section{Hypoglycemia}

Where glucose lowering is needed without risking hypoglycemia, SGLT2 inhibitors have greater glucose-reducing effects than DPP-4 inhibitors when considering a second-line add-on to metformin..$^{50}$ They can also be used in combination with DPP-4 inhibitors, if a three-drug combination is required. ${ }^{26}$ Similarly, a combination of metformin, pioglitazone, and an SGLT2 inhibitor would not be expected to increase the risk of hypoglycemia. ${ }^{21}$ For patients receiving insulin secretagogues (eg, sulfonylureas) or insulin, a dose reduction should be considered when adding empagliflozin to reduce hypoglycemia risk. ${ }^{6}$ In my experience, this is especially important for patients whose $\mathrm{HbA}_{1 \mathrm{c}}$ levels are closer to target.

\section{Hypertension}

The majority of patients with T2DM have hypertension, ${ }^{51}$ and the ADA recommends a BP goal of $<140 / 90 \mathrm{mmHg}$ for patients with diabetes, noting that lower targets may be appropriate in some patients. ${ }^{52}$ Lifestyle advice, including dietary changes and increased activity, is recommended for all patients with $\mathrm{BP}>120 / 80 \mathrm{mmHg}$, with pharmacotherapy for those with BP $>140 / 90 \mathrm{mmHg}$. Typically, multiple drug therapy will be required, and should include an angiotensinconverting enzyme (ACE) inhibitor or an angiotensinreceptor blocker. ${ }^{52}$ An SGLT2 inhibitor would not be chosen specifically to reduce BP or to replace an antihypertensive drug, but the magnitude of antihypertensive effects with empagliflozin might enable patients to achieve BP goals or to reduce their dose of diuretic.

Empagliflozin was studied in patients with T2DM and hypertension (mean seated systolic BP 130-159 mmHg and diastolic BP 80-99 mmHg). ${ }^{27}$ After 12 weeks, empagliflozin 10 and $25 \mathrm{mg}$ significantly reduced mean 24-hour systolic $\mathrm{BP}$, measured via ambulatory BP monitoring (ABPM), versus placebo (adjusted mean difference versus placebo in change from baseline in mean 24-hour systolic BP [ABPM] was $-3.44 \mathrm{mmHg}$ [95\% CI, -4.78 to -2.09 ] with $10 \mathrm{mg}$ empagliflozin and $-4.16 \mathrm{mmHg}$ [ $95 \% \mathrm{CI},-5.50$ to -2.83 ] with $25 \mathrm{mg}$ empagliflozin; $P<0.001$ for both) ${ }^{27}$ One patient on placebo and one patient on empagliflozin $10 \mathrm{mg}$ reported events consistent with volume depletion. ${ }^{27}$ The authors also commented that the risk of hypotension in normotensive patients treated with empagliflozin was low. ${ }^{27}$ This is supported by a meta-analysis of SGLT2 inhibitor clinical trials, in which no significant increase in orthostatic hypotension was detected. ${ }^{53}$ However, the potential for volume depletion events should be considered in patients at risk (eg, elderly, receiving diuretics, low systolic $\mathrm{BP}$ ) before starting therapy with any SGLT2 inhibitor. ${ }^{4-6}$

A further clinical trial is ongoing to study the effect of empagliflozin in African-American patients with T2DM and hypertension (ClinicalTrials.gov identifier: NCT02182830), as this is a patient group at a high risk of macrovascular and microvascular complications in T2DM. ${ }^{54}$

\section{Oral regimens and adherence}

An oral, once-daily treatment is preferable for most patients, ${ }^{55,56}$ consistent with the recommended dosing schedule for currently available SGLT2 inhibitors. Where an SGLT2 inhibitor is used in combination with another oral glucose-lowering agent, a single-pill combination might be considered to reduce pill burden. For empagliflozin, a singlepill combination with the DPP-4 inhibitor linagliptin is approved by the US Food and Drug Administration (FDA) ${ }^{12}$ and under regulatory review by the European Medicines Agency (EMA), while a single-pill combination with metformin is approved by both the EMA and FDA..$^{13,14}$ In practice, unless a patient expresses anxiety about increasing the number of pills, an appropriate regimen can be chosen first, and a single-pill combination considered thereafter (if one is available), rather than single-pill combinations driving the treatment choice.

\section{Treatment safety}

As glucose-lowering drugs will be taken for many years, long-term safety is a primary concern. The long-term cardiovascular safety of empagliflozin was investigated in the EMPA-REG OUTCOME study - as discussed in the Introduction. This was designed first as a safety trial with the option to test for superiority provided all safety end points were met. ${ }^{7}$ The study showed that empagliflozin did not increase the risk of major cardiovascular events, and in fact reduced the risk. Given the large number of patients in the study (7,020 were randomized and treated, and 97\% completed the study), a large amount of information on AEs was also collected for other safety analyses. Notably, the empagliflozin and placebo groups had similar rates of bone fractures, providing reassurance regarding this potential $\mathrm{AE}$ with empagliflozin, while it was recently added as a warning or precaution to the US label of canagliflozin. ${ }^{57}$ In addition, the empagliflozin and placebo groups had similar rates of diabetic ketoacidosis, ${ }^{7}$ a recently identified potential safety issue with SGLT2 inhibitor therapy, following a number of reports in clinical practice. ${ }^{58,59}$ Diabetic ketoacidosis is usually accompanied by high blood glucose levels, although 
blood glucose levels were only moderately increased (ie, euglycemic ketoacidosis) in some of these safety case reports, and one case of euglycemic ketoacidosis in a patient on empagliflozin has been reported in the literature. ${ }^{60}$ The pathophysiological cause of this AE is not yet fully elucidated, but possible mechanisms have been suggested. ${ }^{61}$ While the results seen in EMPA-REG OUTCOME appear to show no increased risk, physicians and patients should pay close attention to possible symptoms. ${ }^{58}$

Many physicians have been wary of using SGLT2 inhibitors because of the risk of UTI or genital infections. Based on my observations in clinical practice, genital infections are unlikely to be a problem in circumcised men. In women, higher genital infection rates have been reported in clinical trials (Tables 2 and 4), and physicians should be aware that some women seen in routine clinical practice will have recurrent infections and will need to discontinue SGLT2 inhibitor therapy. However, other physicians are happy to use SGLT2 inhibitors, given their overall efficacy and safety profile - including the benefit of weight loss. The relationship between SGLT2 inhibitors and risk of UTI is less clear than for genital infections: ${ }^{.62}$ some studies with empagliflozin showed no increased risk, while others reported increased UTI frequency with empagliflozin versus placebo/comparator. The very large EMPA-REG OUTCOME trial showed no difference between placebo and empagliflozin in urinary tract infection rates. ${ }^{7}$ However, a pooled analysis of five empagliflozin studies noted an increase in UTI with empagliflozin, and also that UTI was more likely in patients with a history of chronic or recurrent UTI. ${ }^{6}$

Renal safety and changes in lipid profiles also need consideration. For lipids, monitoring LDL-C and treating with standard of care is recommended, but the underlying cause of changes observed during SGLT2 inhibitor therapy is unexplained. Nevertheless, the long-term cardiovascular safety demonstrated by empagliflozin is encouraging, and the increase in HDL-C seen alongside LDL-C changes has kept the LDL-to-HDL ratio unchanged. Observed eGFR changes with empagliflozin are also currently unexplained, but appear reversible on stopping treatment, and it has been speculated that preglomerular vasoconstriction of hyperfiltering glomeruli may be involved. ${ }^{28}$ Regarding safety in patients with renal impairment, when empagliflozin was studied in patients with stage 2 and 3 CKD over 52 weeks, it was well tolerated, although an increased risk of AEs such as volume depletion events and UTI in stage 4 CKD was acknowledged. ${ }^{28}$

\section{Choosing an SGLT2 inhibitor}

Although this review has focused on empagliflozin, canagliflozin and dapagliflozin are also available in the US and in other parts of the world. Therefore, the question arises of what the potential differences between empagliflozin and other gliflozins are. Currently, there are no head-to-head comparisons of SGLT2 inhibitors: the only direct comparisons are based on pharmacodynamic data in healthy individuals, ${ }^{63}$ or data from preclinical studies. ${ }^{64}$ Although all three SGLT2 inhibitors became available relatively recently, all have extensive clinical development programs, giving a large number of patient-years of experience. However, empagliflozin is the only drug in the class with demonstrated cardiovascular benefit - although cardiovascular outcome trials are underway for dapagliflozin and canagliflozin, these are not expected to complete for several years. ${ }^{65}$ Furthermore, the EMPA-REG OUTCOME investigators have been careful to point out that their study recruited a selected group of patients with higher than average cardiovascular risk. ${ }^{7}$ Therefore, how far the results can be generalized to patients at lower risk is not clear, but it must be borne in mind that no other glucose-lowering agent has been tested and demonstrated benefit in this group. While such studies might be anticipated, the results would likely not be available for many years; in the meantime, empagliflozin would appear to be the preferred agent when starting an SGLT2 inhibitor is being considered.

The further key difference between the three agents is in the level of renal impairment allowed by US prescribing information (Table 6). ${ }^{4-6}$ While some experts argue that lack of an effect with dapagliflozin in patients with CKD likely results from underpowered studies, ${ }^{66}$ in practice, the precautions advised by the FDA for patients with moderate renal impairment will make a difference as to which agent

Table 6 Dosage and administration of SGLT2 inhibitors according to renal function (eGFR)

\begin{tabular}{|c|c|}
\hline \multirow[t]{4}{*}{ Canagliflozin ${ }^{4}$} & $\begin{array}{l}\text { Assess renal function before initiating canagliflozin } \\
\text { therapy }\end{array}$ \\
\hline & $\begin{array}{l}\text { Canagliflozin is limited to } 100 \mathrm{mg} \text { once daily in patients } \\
\text { who have an eGFR of } 45 \text { to }<60 \mathrm{~mL} / \mathrm{min} / 1.73 \mathrm{~m}^{2}\end{array}$ \\
\hline & $\begin{array}{l}\text { Do not initiate canagliflozin if eGFR is }<45 \mathrm{~mL} / \\
\mathrm{min} / 1.73 \mathrm{~m}^{2}\end{array}$ \\
\hline & $\begin{array}{l}\text { Discontinue canagliflozin if eGFR falls persistently } \\
\text { below } 45 \mathrm{~mL} / \mathrm{min} / 1.73 \mathrm{~m}^{2}\end{array}$ \\
\hline \multirow[t]{3}{*}{ Dapagliflozin ${ }^{5}$} & $\begin{array}{l}\text { Assess renal function before initiating dapagliflozin } \\
\text { therapy }\end{array}$ \\
\hline & Do not initiate if eGFR $<60 \mathrm{~mL} / \mathrm{min} / 1.73 \mathrm{~m}^{2}$ \\
\hline & $\begin{array}{l}\text { Discontinue dapagliflozin if eGFR falls persistently } \\
\text { below } 60 \mathrm{~mL} / \mathrm{min} / 1.73 \mathrm{~m}^{2}\end{array}$ \\
\hline \multirow[t]{3}{*}{ Empagliflozin ${ }^{6}$} & $\begin{array}{l}\text { Assess renal function before initiating empagliflozin } \\
\text { therapy }\end{array}$ \\
\hline & $\begin{array}{l}\text { Do not initiate empagliflozin if eGFR is }<45 \mathrm{~mL} / \\
\mathrm{min} / \mathrm{I} .73 \mathrm{~m}^{2}\end{array}$ \\
\hline & $\begin{array}{l}\text { Discontinue empagliflozin if eGFR falls persistently } \\
\text { below } 45 \mathrm{~mL} / \mathrm{min} / 1.73 \mathrm{~m}^{2}\end{array}$ \\
\hline
\end{tabular}

Abbreviation: eGFR, estimated glomerular filtration rate. 
is chosen. If FDA prescribing information is followed, dapagliflozin would need to be discontinued at higher eGFR levels (ie, eGFR persistently $<60 \mathrm{~mL} / \mathrm{min} / 1.73$ $\left.\mathrm{m}^{2}\right),{ }^{5}$ while canagliflozin would require dose reduction at higher eGFR levels than empagliflozin (canagliflozin is limited to $100 \mathrm{mg}$ once daily with eGFR of 45 to $<60$ $\left.\mathrm{mL} / \mathrm{min} / 1.73 \mathrm{~m}^{2}\right) .^{4}$

\section{Conclusion}

The empagliflozin clinical trials program was designed to test empagliflozin in various combination regimens, and in a range of T2DM patient subpopulations: the resulting data have shown that empagliflozin is worth considering as an addition to the treatment regimen of many patients with T2DM, provided they have sufficient renal function. Empagliflozin has the potential to make an important contribution to the treatment of T2DM in combination therapies in patients with poor glucose control, with the added advantages of body weight loss and $\mathrm{BP}$ reduction.

\section{Acknowledgment}

The author received no direct compensation related to the development of the manuscript. Medical writing support for the preparation of this manuscript was provided by Debra Brocksmith and Geraldine Thompson of Envision Scientific Solutions, which was contracted and funded by Boehringer Ingelheim Pharmaceuticals, Inc, the manufacturer of empagliflozin. Boehringer Ingelheim Pharmaceuticals, Inc. was given the opportunity to review the manuscript for medical and scientific accuracy as well as intellectual property considerations.

\section{Disclosure}

The author reports no conflicts of interest in this work.

\section{References}

1. Abdul-Ghani MA, DeFronzo RA. Inhibition of renal glucose reabsorption: a novel strategy for achieving glucose control in type 2 diabetes mellitus. Endocr Pract. 2008;14(6):782-790.

2. DeFronzo RA, Davidson JA, Del Prato S. The role of the kidneys in glucose homeostasis: a new path towards normalizing glycaemia. Diabetes Obes Metab. 2012;14(1):5-14.

3. Oliva RV, Bakris GL. Blood pressure effects of sodium-glucose co-transport 2 (SGLT2) inhibitors. J Am Soc Hypertens. 2014;8(5): 330-339.

4. INVOKANA® (canagliflozin) tablets for oral use [prescribing information]. Titusville, NJ: Janssen Pharmaceuticals, Inc; 2015.

5. FARXIGA® (dapagliflozin) tablets for oral use [prescribing information]. Wilmington, DE: AstraZeneca Pharmaceuticals LP; 2015.

6. JARDIANCE® (empagliflozin) tablets for oral use [prescribing information]. Ridgefield, CT: Boehringer Ingelheim Pharmaceuticals, Inc; 2015.
7. Zinman B, Wanner C, Lachin JM, et al. Empagliflozin, cardiovascular outcomes, and mortality in type 2 diabetes. $N$ Engl $J$ Med. 2015;373(22):2117-2128.

8. UK Prospective Diabetes Study (UKPDS) Group. Effect of intensive blood-glucose control with metformin on complications in overweight patients with type 2 diabetes (UKPDS 34). Lancet. 1998;352(9131):854-865.

9. Dormandy JA, Charbonnel B, Eckland DJ, et al. Secondary prevention of macrovascular events in patients with type 2 diabetes in the PROactive study (PROspective pioglitAzone Clinical Trial In macroVascular Events): a randomised controlled trial. Lancet. 2005;366(9493):1279-1289.

10. Liakos A, Karagiannis T, Athanasiadou E, et al. Efficacy and safety of empagliflozin for type 2 diabetes: a systematic review and meta-analysis. Diabetes Obes Metab. 2014;16(10):984-993.

11. Chen M, Xie CG, Gao H, Zheng H, Chen Q, Fang JQ. Comparative effectiveness of sodium-glucose co-transporter 2 inhibitors for controlling hyperglycaemia in patients with type 2 diabetes: protocol for a systematic review and network meta-analysis. BMJ Open. 2016;6(1):e010252.

12. GLYXAMBI ${ }^{\circledR}$ (empagliflozin and linagliptin) tablets for oral use [prescribing information]. Ridgefield, CT: Boehringer Ingelheim Pharmaceuticals, Inc; 2015.

13. SYNJARDY ${ }^{\circledR}$ (empagliflozin and metformin hydrochloride) tablets for oral use [prescribing information]. Ridgefield, CT: Boehringer Ingelheim Pharmaceuticals, Inc; 2015.

14. European Medicines Agency. Summary of Product Characteristics (June 12, 2015): Synjardy (empagliflozin/metformin film-coated tablets). Available from: http://www.ema.europa.eu/docs/en_GB/ document_library/EPAR_-_Product_Information/human/003770/ WC500187999.pdf. Accessed September 8, 2015.

15. Roden M, Weng J, Eilbracht J, et al. Empagliflozin monotherapy with sitagliptin as an active comparator in patients with type 2 diabetes: a randomised, double-blind, placebo-controlled, phase 3 trial. Lancet Diabetes Endocrinol. 2013;1(3):208-219.

16. Ferrannini E, Seman L, Seewaldt-Becker E, Hantel S, Pinnetti S, Woerle HJ. A phase IIb, randomized, placebo-controlled study of the SGLT2 inhibitor empagliflozin in patients with type 2 diabetes. Diabetes Obes Metab. 2013;15(8):721-728.

17. Kadowaki T, Haneda M, Inagaki N, et al. Empagliflozin monotherapy in Japanese patients with type 2 diabetes mellitus: a randomized, 12-week, double-blind, placebo-controlled, phase II trial. Adv Ther. 2014;31(6):621-638.

18. Rosenstock J, Seman LJ, Jelaska A, et al. Efficacy and safety of empagliflozin, a sodium glucose cotransporter 2 (SGLT2) inhibitor, as add-on to metformin in type 2 diabetes with mild hyperglycaemia. Diabetes Obes Metab. 2013;15(12):1154-1160.

19. Häring HU, Merker L, Seewaldt-Becker E, et al. Empagliflozin as add-on to metformin in patients with type 2 diabetes: a 24-week, randomized, double-blind, placebo-controlled trial. Diabetes Care. 2014;37(6):1650-1659.

20. Ridderstråle M, Andersen KR, Zeller C, Kim G, Woerle HJ, Broedl UC. Comparison of empagliflozin and glimepiride as add-on to metformin in patients with type 2 diabetes: a 104-week randomised, activecontrolled, double-blind, phase 3 trial. Lancet Diabetes Endocrinol. 2014;2(9):691-700.

21. Kovacs CS, Seshiah V, Swallow R, et al. Empagliflozin improves glycaemic and weight control as add-on therapy to pioglitazone or pioglitazone plus metformin in patients with type 2 diabetes: a 24-week, randomized, placebo-controlled trial. Diabetes Obes Metab. 2014;16(2):147-158.

22. Häring HU, Merker L, Seewaldt-Becker E, et al. Empagliflozin as add-on to metformin plus sulfonylurea in patients with type 2 diabetes: a 24-week, randomized, double-blind, placebo-controlled trial. Diabetes Care. 2013;36(11):3396-3404.

23. Rosenstock J, Jelaska A, Frappin G, et al. Improved glucose control with weight loss, lower insulin doses, and no increased hypoglycemia with empagliflozin added to titrated multiple daily injections of insulin in obese inadequately controlled type 2 diabetes. Diabetes Care. 2014;37(7):1815-1823. 
24. Ferrannini E, Berk A, Hantel S, et al. Long-term safety and efficacy of empagliflozin, sitagliptin, and metformin: an active-controlled, parallelgroup, randomized, 78-week open-label extension study in patients with type 2 diabetes. Diabetes Care. 2013;36(12):4015-4021.

25. Lewin A, DeFronzo RA, Patel S, et al. Initial combination of empagliflozin and linagliptin in subjects with type 2 diabetes. Diabetes Care. 2015;38(3):394-402.

26. DeFronzo RA, Lewin A, Patel S, et al. Combination of empagliflozin and linagliptin as second-line therapy in subjects with type 2 diabetes inadequately controlled on metformin. Diabetes Care. 2015;38(3):384-393

27. Tikkanen I, Narko K, Zeller C, et al. Empagliflozin reduces blood pressure in patients with type 2 diabetes and hypertension. Diabetes Care. 2015;38(3):420-428.

28. Barnett AH, Mithal A, Manassie J, et al. Efficacy and safety of empagliflozin added to existing antidiabetes treatment in patients with type 2 diabetes and chronic kidney disease: a randomised, double-blind, placebo-controlled trial. Lancet Diabetes Endocrinol. 2014;2(5) 369-384.

29. Ross S, Thamer C, Cescutti J, Meinicke T, Woerle HJ, Broedl UC Efficacy and safety of empagliflozin twice daily versus once daily in patients with type 2 diabetes inadequately controlled on metformin: a 16-week, randomized, placebo-controlled trial. Diabetes Obes Metab 2015;17(7):699-702.

30. Rosenstock J, Jelaska A, Zeller C, Kim G, Broedl UC, Woerle HJ. Impact of empagliflozin added on to basal insulin in type 2 diabetes inadequately controlled on basal insulin: a 78-week randomized, double-blind, placebo-controlled trial. Diabetes Obes Metab. 2015; 17(10):936-948.

31. American Diabetes Association. Standards of medical care in diabetes (section 7). Approaches to glycemic treatment. Diabetes Care. 2015; 38(Suppl):S41-S48.

32. Inzucchi SE, Bergenstal RM, Buse JB, et al. Management of hyperglycemia in type 2 diabetes, 2015: a patient-centered approach: update to a position statement of the American Diabetes Association and the European Association for the Study of Diabetes. Diabetes Care. 2015;38(1):140-149

33. $\operatorname{ACTOS}^{\circledR}$ (pioglitazone) tablets for oral use [prescribing information]. Deerfield, IL: Takeda Pharmaceuticals America, Inc; 2013.

34. Neumann A, Weill A, Ricordeau P, Fagot JP, Alla F, Allemand H. Pioglitazone and risk of bladder cancer among diabetic patients in France: a population-based cohort study. Diabetologia. 2012;55(7):1953-1962.

35. Hampp C, Borders-Hemphill V, Moeny DG, Wysowski DK. Use of antidiabetic drugs in the US, 2003-2012. Diabetes Care. 2014;37(5):1367-1374.

36. Oyer D, Cashin K, Gong J. Impact of canagliflozin in type 2 diabetic patients in a real world setting. Endocr Pract. 2015;21(Suppl 2): 56 (Abstract \#264).

37. Mcgovern AP, Dutta N, Watters K, Munro N, Feher M. Additive weight loss effect with a combination of an oral sodium-glucose cotransporter 2 (SGLT2) inhibitor and a glucagon-like peptide 1 (GLP-1) agonist in Type 2 diabetes. Diabet Med. 2015;32(S1):2-3 (Abstract \#A6).

38. American Diabetes Association. Standards of medical care in diabetes (section 6). Glycemic targets. Diabetes Care. 2015;38(Suppl):S33-S40.

39. Esposito K, Cozzolino D, Bellastella G, et al. Dipeptidyl peptidase-4 inhibitors and $\mathrm{HbA}_{1 \mathrm{c}}$ target of $<7 \%$ in type 2 diabetes: meta-analysis of randomized controlled trials. Diabetes Obes Metab. 2011;13(7): 594-603.

40. Balkau B, Calvi-Gries F, Freemantle N, Vincent M, Pilorget V, Home PD. Predictors of $\mathrm{HbA}_{1 \mathrm{c}}$ over 4 years in people with type 2 diabetes starting insulin therapies: the CREDIT study. Diabetes Res Clin Pract. 2015;108(3):432-440.

41. Handelsman Y, Bloomgarden ZT, Grunberger G, et al. American Association of Clinical Endocrinologists and American College of Endocrinology - clinical practice guidelines for developing a diabetes mellitus comprehensive care plan - 2015. Endocr Pract. 2015;21(0):1-87.
42. Wilding JP. The importance of weight management in type 2 diabetes mellitus. Int J Clin Pract. 2014;68(6):682-691.

43. Diabetes Prevention Program Research Group. Long-term safety, tolerability, and weight loss associated with metformin in the Diabetes Prevention Program Outcomes Study. Diabetes Care. 2012;35(4): 731-737.

44. Vilsbøll T, Christensen M, Junker AE, Knop FK, Gluud LL. Effects of glucagon-like peptide-1 receptor agonists on weight loss: systematic review and meta-analyses of randomised controlled trials. BMJ. 2012;344:d7771.

45. Cicero AF, Tartagni E, Ertek S. Metformin and its clinical use: new insights for an old drug in clinical practice. Arch Med Sci. 2012;8(5):907-917.

46. FDA News Release. FDA Approves Weight-Management Drug Saxenda. December 23, 2014. Silver Spring, MD: Food and Drug Administration. Available from: http://www.fda.gov/NewsEvents/Newsroom/PressAnnouncements/ucm427913.htm. Accessed July 1, 2015.

47. Saxenda Summary of Product Characteristics April 2015. Available from: http://www.ema.europa.eu/docs/en_GB/document_library/ EPAR_-_Product_Information/human/003780/WC500185786.pdf. Accessed June 9, 2015.

48. Bailey RA, Wang Y, Zhu V, Rupnow MF. Chronic kidney disease in US adults with type 2 diabetes: an updated national estimate of prevalence based on Kidney Disease: Improving Global Outcomes (KDIGO) staging. BMC Res Notes. 2014;7:415.

49. Moen MF, Zhan M, Hsu VD, et al. Frequency of hypoglycemia and its significance in chronic kidney disease. Clin J Am Soc Nephrol. 2009;4(6):1121-1127.

50. Schernthaner G, Gross JL, Rosenstock J, et al. Canagliflozin compared with sitagliptin for patients with type 2 diabetes who do not have adequate glycemic control with metformin plus sulfonylurea: a 52-week randomized trial. Diabetes Care. 2013;36(9):2508-2515.

51. Ferrannini E, Cushman WC. Diabetes and hypertension: the bad companions. Lancet. 2012;380(9841):601-610.

52. American Diabetes Association. Standards of medical care in diabetes (section 8). Cardiovascular disease and risk management. Diabetes Care. 2015;38(Suppl):S49-S57.

53. Baker WL, Smyth LR, Riche DM, Bourret EM, Chamberlin KW, White WB. Effects of sodium-glucose co-transporter 2 inhibitors on blood pressure: a systematic review and meta-analysis. J Am Soc Hypertens. 2014;8(4):262-275.e269.

54. Ferdinand KC, Nasser SA. Racial/ethnic disparities in prevalence and care of patients with type 2 diabetes mellitus. Curr Med Res Opin. 2015;31(5):913-923.

55. Kruger DF, LaRue S, Estepa P. Recognition of and steps to mitigate anxiety and fear of pain in injectable diabetes treatment. Diabetes Metab Syndr Obes. 2015;8:49-56.

56. Polonsky WH, Hajos TR, Dain MP, Snoek FJ. Are patients with type 2 diabetes reluctant to start insulin therapy? An examination of the scope and underpinnings of psychological insulin resistance in a large, international population. Curr Med Res Opin. 2011;27(6):1169-1174.

57. Food and Drug Administration. FDA Drug Safety Communication: FDA Revises Label of Diabetes Drug Canagliflozin (Invokana, Invokamet) to Include Updates on Bone Fracture Risk and New Information on Decreased Bone Mineral Density. Silver Spring, MD: Food and Drug Administration. Available from: http://www.fda.gov/downloads/Drugs/ DrugSafety/UCM461790.pdf. Accessed September 25, 2015.

58. US Food and Drug Administration. Drug Safety Communications (15 May 2015): FDA Warns that SGLT2 Inhibitors for Diabetes may Result in a Serious Condition of too Much Acid in the Blood. Silver Spring, MD: Food and Drug Administration. Available from: http://www.fda.gov/downloads/ Drugs/DrugSafety/UCM446954.pdf. Accessed June 25, 2015.

59. European Medicines Agency. Review of Diabetes Medicines Called SGLT2 Inhibitors Started (12 June 2015). Canary Wharf, London: European Medicines Agency. Available from: http://www.ema.europa.eu/docs/ en_GB/document_library/Referrals_document/SGLT2_inhibitors_20/ Procedure_started/WC500187926.pdf. Accessed June 25, 2015. 
60. Roach P, Skierczynski P. Euglycemic diabetic ketoacidosis in a patient with type 2 diabetes after treatment with empagliflozin. Diabetes Care. 2016;39(1):e3.

61. Taylor SI, Blau JE, Rother KI. SGLT2 inhibitors may predispose to ketoacidosis. J Clin Endocrinol Metab. 2015;100(8):2849-2852.

62. Geerlings S, Fonseca V, Castro-Diaz D, List J, Parikh S. Genital and urinary tract infections in diabetes: impact of pharmacologically-induced glucosuria. Diabetes Res Clin Pract. 2014;103(3):373-381.

63. Sha S, Polidori D, Farrell K, et al. Pharmacodynamic differences between canagliflozin and dapagliflozin: results of a randomized, doubleblind, crossover study. Diabetes Obes Metab. 2015;17(2):188-197.
64. Grempler R, Thomas L, Eckhardt M, et al. Empagliflozin, a novel selective sodium glucose cotransporter-2 (SGLT-2) inhibitor: characterisation and comparison with other SGLT-2 inhibitors. Diabetes Obes Metab. 2012;14(1):83-90.

65. Inzucchi SE, Zinman B, Wanner C, et al. SGLT-2 inhibitors and cardiovascular risk: proposed pathways and review of ongoing outcome trials. Diab Vasc Dis Res. 2015;12(2):90-100.

66. Gilbert RE. The perils of clinical trials. Kidney Int. 2014;85(4): 745-747.

\section{Publish your work in this journal}

The International Journal of General Medicine is an international, peer-reviewed open-access journal that focuses on general and internal medicine, pathogenesis, epidemiology, diagnosis, monitoring and treatment protocols. The journal is characterized by the rapid reporting of reviews, original research and clinical studies across all disease areas.
A key focus is the elucidation of disease processes and management protocols resulting in improved outcomes for the patient. The manuscript management system is completely online and includes a very quick and fair peer-review system. Visit http://www.dovepress.com/ testimonials.php to read real quotes from published authors.

Submit your manuscript here: http://www.dovepress.com/international-journal-of-general-medicine-journal 